\title{
Chemical herding of weathered crude oils for in-situ burning
}

Rojas-Alva, Ulises; Andersen, Bjørn Skjønning; Jomaas, Grunde

Published in:

Journal of Environmental Management

Link to article, DOI:

10.1016/j.jenvman.2019.109470

Publication date:

2019

Document Version

Peer reviewed version

Link back to DTU Orbit

Citation (APA):

Rojas-Alva, U., Andersen, B. S., \& Jomaas, G. (2019). Chemical herding of weathered crude oils for in-situ burning. Journal of Environmental Management, 250, [109470]. https://doi.org/10.1016/j.jenvman.2019.109470

\section{General rights}

Copyright and moral rights for the publications made accessible in the public portal are retained by the authors and/or other copyright owners and it is a condition of accessing publications that users recognise and abide by the legal requirements associated with these rights.

- Users may download and print one copy of any publication from the public portal for the purpose of private study or research.

- You may not further distribute the material or use it for any profit-making activity or commercial gain

- You may freely distribute the URL identifying the publication in the public portal

If you believe that this document breaches copyright please contact us providing details, and we will remove access to the work immediately and investigate your claim 


\title{
Chemical herding of weathered crude oils for in-situ burning
}

\author{
U. Rojas Alva ${ }^{\mathrm{a}, \mathrm{b}}$, Bjørn Skjønning Andersen ${ }^{\mathrm{a}}$, Grunde Jomaas ${ }^{\mathrm{a}, \mathrm{b}}$ \\ ${ }^{a}$ Civil Engineering Department, Technical University of Denmark, Denmark \\ ${ }^{\mathrm{b}}$ School of Engineering, BRE Centre for Fire Safety Engineering, The University of \\ Edinburgh, United Kingdom
}

\begin{abstract}
Mid-scale ISB experiments were conducted in a large water-basin $\left(20 \mathrm{~m}^{2} \times 1 \mathrm{~m}\right)$ in order to assess the applicability of chemical herding of weathered crude oil spills on water in association with in-situ burning (ISB). A silicone-based chemical herding agent, OP-40, was used to confine, or herd, three different crude oils (Siri, Grane and Oseberg blend) at various weathering degrees. The herding agent was capable of obtaining the minimum required oil slick thickness for ignition and subsequent flame spread in most of the experiments, but not for the strongly weathered oils. Also, the herding agent was capable of re-thickening the oil slick after flame extinction. The burning efficiency results indicate that the method can be viable for ISB with herders at a larger scale, and suggest that the burning efficiency scales with the amount of crude oil. Sinking behaviour of residues was also observed and quantified, as such a behaviour can pose a serious environmental threat in real scenarios.
\end{abstract}

Keywords: Oil spill, Herding, Burning efficiency, regression rate, pollution

\section{Introduction}

Spillage of crude oil in Arctic and Antarctic waters has become a crucial issue for fragile local environments. There is an increasing concern from governments and private companies over the occurrence and impact of oil spills in the sea and its efficient removal. Due to global warming, over the last decade, there has been a reduction of ice-presence in the Arctic and a reduction of average sailing times through the various shipping routes. As a consequence, the Arctic shipping routes are experiencing increasing pressure on cargo transportation (Aksenov et al., 2017). In addition, there is also an increasing pressure of cruise ship activity in the Antarctic waters and an increase of oil spills from vessels has been reported (Filler et al., 2015). Further to this, Norway has recently announced the exploitation of their oil reserves under the Barents Sea where several wells are going to be drilled. Other countries with territorial waters in the Arctic sea are expected to commence with similar activities. The occurrence of oil spills 
due to the breakup of pipelines or wells and vessels are apparent. A well-known example of how devastating such an event can be is the Deepwater Horizon oil spill in the Gulf of Mexico (The Federal Interagency Solutions Group, 2010). Oil spills in cold regions waters have also been reported (Filler et al., 2015).

There are various cleaning methods to remove the oil spill from open waters, such as mechanical extraction, chemical dispersion, in-situ burning among others (Fingas, 2011a; Nuka, Research \& Planning Group, 2010). In-situ burning (ISB) is an on-site burning of an oil spill that allows the conversion of the oil hydrocarbon components into combustion products such as carbon monoxide, soot, and other gases that are released to the atmosphere (Buist et al., 2013). This technique has been proven to be effective for large oil spills (Bech et al., 1992; Shi et al., 2016). In the Arctic context, ISB was identified as the most effective solution (due to remoteness and ice-infested waters) (Bullock et al., 2019; Fritt-Rasmussen et al., 2012; Shi et al., 2016; Van Gelderen et al., 2015). In fact, various studies have reported that more than 90\% of an oil spill can be removed using in-situ burning (Aggarwal et al., 2017; Buist et al., 2011, 2013; Buist and Twardus, 1985; Fingas et al., 1995; Van Gelderen et al., 2015).

Once the oil is spilled over the sea, it expands and decreases in thickness owing to the sea and climatological conditions. To successfully achieve in-situ burning, i.e., to achieve ignition and subsequent burning of the crude oil, a minimum oil slick thickness is necessary (Nordvik et al., 2003). Confinement, either mechanical or chemical, is needed to maintain a minimum oil slick thickness throughout the burning process. Mechanical confinement requires fire-resistant booms (barriers) deployed and managed by vessels. This technique can prove challenging in the Arctic and Antarctic waters due to remoteness and the presence of drifting-ice. It is worth noting that physical confinement can also occur naturally, e.g., in ice cavities, due to the wind, between ice blocks (Aggarwal et al., 2017; Dickins et al., 2008; Energetex Engineering, 1981; Fritt-Rasmussen and Brandvik, 2011).

Chemical confinement presents advantages over the mechanical option. The chemical agents used for chemical confinement are commonly known as "herders". These chemical herders push the oil due to the difference in surface tension between the oil and the monolayer created by herder surrounding the oil (Buist et al., 2008a, 2011, 2013). Using chemical herding agents has shown promising results in achieving large oil removal rates or burning efficiencies (BE) for the in-situ burning method in the Arctic and Antarctic conditions alike (Buist et al., 2011; Buist and Potter, 2010; Dickins et al., 2008). Currently, two herding agents are listed in the U.S. Environmental Protection Agency NCP Product Schedule (Nedwed et al., 2012). These herding agents are the hydrocarbon-based formulation ThickSlick 6535 (TS6535), and the silicone-based herder, OP-40 (Lane et al., 2012). Recent studies have shown that OP-40 has better herding capabilities than TS6535 for fresh-crude oils (Aggarwal et al., 2017; Buist et al., 2009; Bullock et al., 2017; Potter et al., 2016; van Gelderen et al., 2016).

When spilled on open waters, the crude oil immediately undergoes a weathering process that depends on many variables (Brandvik and Faksness, 2009; Fritt-Rasmussen et al., 2012; Garo et al., 2004). Two of the most relevant weathering processes are evaporation (the crude oil's lighter components evaporate) and emulsification (the oil mixes with water due to wave action) (Brandvik and Faksness, 2009; Buist et al., 2013). The degree of evaporation and the content of specific components in the crude oil, asphaltenes and resins, support the formation and stability of water-in-oil emulsion (Fingas and Fieldhouse, 2015). The stability degree of emulsification determines the ignitability of an emulsified crude oil (Buist et al., 2013). That is, for more stable emulsions (due to the higher content of water), it will be nearly impossible to ignite and develop flame spread. Thus, the weathering will influence the overall burning behaviour of the spilled oil during ISB (Fritt-Rasmussen et al., 2012; Fritt-Rasmussen and 
Brandvik, 2011; Guénette et al., 1995). Consequently, in a remote location (such as in the Arctic), the ISB responders are quite likely to encounter a weathered crude oil. Previous ISB studies with herders have mainly focused on fresh crude oils (Aggarwal et al., 2017; Buist et al., 2007, 2008a, 2010, 2011, 2017; Bullock et al., 2017; Rojas Alva et al., 2018; Singsaas et al., 2017; van Gelderen et al., 2016). However, little is known about its ability to thicken weathered or emulsified crude oils for in-situ burning.

The burning efficiency has been found to show discrepancies as a function of the oil slick size, especially in small-scale laboratory experiments (Buist, 2006; Buist et al., 2008a, 2011). One reason for this is that boilover (sudden splash of waterbed under the fuel due to nucleation of water) has been reported to disrupt the burning during ISB in small-scale experiments (Brogaard et al., 2014; Evans et al., 2001; Rojas Alva et al., 2018; Van Gelderen et al., 2015). In large-scale and more realistic operational scenarios (in open waters), boilover has not been observed according to literature. Consequently, it is difficult to extrapolate the burning behaviour from small-scale (environment/experiments) testing to more-realistic scenarios.

Based on the findings and knowledge gaps presented above, two objectives were set for the current study. The first objective was to study the thickening effectiveness of the silicone herding agent on various weathered crude oils before and during burning. The second objective was to study the burning behaviour of the chemically herded crude oils during and after ISB. For the latter, two ISB specific parameters were estimated, namely the burning efficiency (BE) and the regression rate. In addition, the sinking behaviour of the post-burn residues was observed.

\section{Methodology}

For this study, various amounts (1.6 to 25 1.) of three artificially weathered crude oils (Siri, Grane and Oseberg Blend) were selected and the silicone-based herding agent (OP-40) was used. The mid-scale experiments were conducted in a large water basin $\left(20 \mathrm{~m}^{2}\right)$ in the outdoors, see Figure 1, to avoid boilover and to produce a small oil-to-water ratio, thus recreating realistic scenarios.
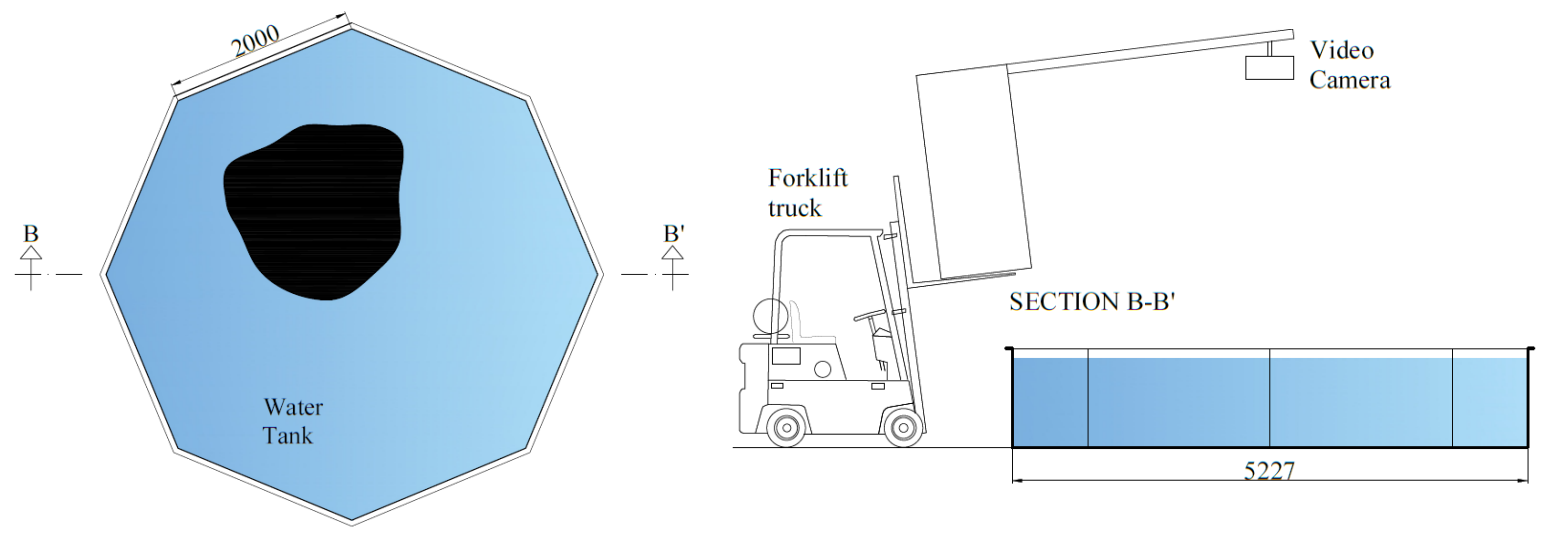

Figure 1 - The mid-scale experimental set-up. The left schematic shows a top view and the right schematic a side-view. Dimensions are in $\mathrm{mm}$.

Three crude oils were chosen for this study; these were Grane, Oseberg blend and Siri. Grane (Norway) is an asphaltenic crude oil, rich in resins and asphaltenes. The density of Grane crude oil is high, and the evaporative loss is low (Brandvik et al., 2010; Fritt-Rasmussen, 2010). Oseberg is a blend of crude oil from the Oseberg, Brage and Veslefrikk fields (Norway). Oseberg blend is a light, intermediate low-sulphur North Sea crude oil similar in quality to 
Brent (ExxonMobil, 2018). Siri (Danish) is paraffinic crude oil with a high content of waxy components and medium evaporative losses. Grane and Siri oils are representative of two of the four groups of crude oils categorized by SINTEF. However, the Oseberg blend cannot be tentatively categorized because relevant data has not been found in the literature. The physical properties of the crude oils are listed in Table 1.

Table 1 - Physical properties of the fresh crude oils and the herding agent. All of the properties were extracted from the corresponding MSDS sheets.

\begin{tabular}{cccccccc}
\hline $\begin{array}{c}\text { Oil/ } \\
\text { Herder }\end{array}$ & $\begin{array}{c}\text { Asphaltene } \\
\text { content } \\
{[\mathrm{wt} \%]}\end{array}$ & $\begin{array}{c}\text { Paraffin } \\
\text { content } \\
{[\mathrm{wt} \%]}\end{array}$ & $\begin{array}{c}\text { Naphthene } \\
\text { content } \\
{[\mathrm{wt} \%]}\end{array}$ & $\begin{array}{c}\text { Density at } \\
15.5^{\circ} \mathrm{C} \\
{\left[\mathrm{g} / \mathrm{cm}^{3}\right]}\end{array}$ & $\begin{array}{c}\text { Pour } \\
\text { point } \\
{\left[{ }^{\circ} \mathrm{C}\right]}\end{array}$ & $\begin{array}{c}\text { Viscosity at } \\
20{ }^{\circ} \mathrm{C} \\
{[\mathrm{mPas}]}\end{array}$ & $\begin{array}{c}\text { Flash- } \\
\text { point }\left[{ }^{\circ} \mathrm{C}\right]\end{array}$ \\
\hline Grane & 0.9 & 24.6 & 37.3 & 0.89 & 1.3 & 23.1 & $20-21$ \\
\hline Siri & 0.35 & & & 0.84 & 9 & & 10 \\
\hline Oseberg blend & 0.2 & 36.5 & 40.1 & 0.83 & -15 & 4.1 & -24 \\
\hline OP40 & & & & 0.99 & 23.4 & $10-40$ & $>100^{*}$ \\
\hline
\end{tabular}

The herding agent used in the experiment (OP-40) is silicone-based with high thermal stability and behaves like a liquid at room temperature, and it is a standard silicone copolymer, which is considered a non-ionic amphiphilic copolymer (Kunieda et al., 2001). OP-40 can be found in common applications (cleaning products, hair condition, etc.). Table 1 lists the physical properties of OP-40 and further information can be found in (Rojas-Alva et al., 2019a).

The experimental matrix for the study presented herein is displayed in Table 2. The Grane crude oil was only tested in fresh conditions for two amounts, 1.6 and 20 litres, as it served as a benchmark for comparison with previously reported results (Buist et al., 2017; Rojas-Alva et al., 2019a). The Siri crude oil was only subjected to evaporation at a degree of $15 \%$, and various amounts were employed in the experiments (from 2 to 25 litres). The Oseberg blend was evaporated at two degrees (25 and 40\%) and evaporated at 40\% combined with an emulsification degree of $40 \%$ water content, see Figure 2. For the evaporated Oseberg blend, intermediate amounts were used in the experiments ( 7 to 14 litres). Lastly, a strongly weathered Oseberg blend, evaporated at $>40 \%$ and emulsified at 50\% (water content), was tested at large quantities (25 litres). This Oseberg blend was weathered at SINTEF SeaLab in Trondheim.

Table 2 - Experimental matrix indicating the test conditions as a function of the evaporation degree and water content (*weathered Oseberg blend provided by SINTEF).

\begin{tabular}{lcc} 
Oil type & Evaporation degree [\%] & Water content $[\%]$ \\
\hline Grane & 0 & 0 \\
\hline Siri & 15 & 0 \\
\hline Oseberg blend & 25 and 40 & 0 and 40 \\
\hline Oseberg blend* & $>40$ & 50 \\
\hline
\end{tabular}

For this study, the crude oils were artificially evaporated and emulsified to various degrees with the aim of reproducing the scenarios when an oil spill occurs. The evaporation of the crude oils was done by injecting air bubbles from a pressurized vessel to the bottom of a container with the crude oil. The artificial evaporation method used for this experimental study has been used in previous investigations (Buist et al., 2008b; Buist and Glover, 1995; Opstad and Guénette, 2000; S.L. Ross Environmental Research Ltd., 2007). The method was carried out until the desirable evaporation degree was obtained. The crude oil was mixed with artificial sea-water (32\%o salinity) to emulsify the crude oil (evaporated). A tank containing both the 
crude oil and the sea-water was placed on a shaking table for 24 hours at $190 \mathrm{rpm}$. The density and viscosity of all fresh and evaporated crude oils are listed in Table 3.

Table 3 - Physical properties of the weathered crude oils. The densities and viscosities were determined by the Paar Stabinger Viscometer SVM 3000 apparatus*.

\begin{tabular}{ccccc}
\hline \multirow{2}{*}{ Oil } & $\begin{array}{c}\text { Evaporation } \\
\text { degree [\%] }\end{array}$ & $\begin{array}{c}\text { Water } \\
\text { content }[\%]\end{array}$ & $\begin{array}{c}\text { Density at } \\
25{ }^{\circ} \mathrm{C}\left[\mathrm{g} / \mathrm{cm}^{3}\right]\end{array}$ & $\begin{array}{c}\text { Viscosity at 25 } \\
{ }^{\circ} \mathrm{C}[\mathrm{mPas}]\end{array}$ \\
\hline Siri & 15 & 0 & 0.88 & 20 \\
\hline \multirow{2}{*}{ Oseberg blend } & 25 & 0 & 0.86 & 11 \\
\cline { 2 - 5 } & 40 & 0 & 0.87 & 19 \\
\hline $\begin{array}{c}\text { Oseberg blend } \\
\text { (SINTEF) }\end{array}$ & 40 & 40 & 0.95 & 99 \\
\hline
\end{tabular}

*The viscometer follows various standards for measuring kinematic viscosities (ASTM D7042, EN16896, and DIN 51659-2) and the density (EN ISO 12185, ASTM D4052, and IP 365).

For each experiment, the weathered crude oil was poured onto the water basin and left to spread for 30 minutes. Thereafter, $150 \mu \mathrm{l}$ of the herding agent OP-40 was applied per $\mathrm{m}^{2}$ of surface water, as this is the recommended operational dose (Buist et al., 2017, 2011, 2009; van Gelderen et al., 2016). It was applied from the edge of the basin to thicken the oil slick centrally. During the herding process, a camera placed above the water basin was used to estimate the oil slick area (and hence thickness) and flame areas, see Figure 1. In some of the experiments, the water was pre-treated with the herding agent (before the oil was poured) to minimize the influence of wind and to optimise the number of experiments.

After the herding procedure was completed, an igniter promoter made of gelled gasoline-diesel mixture was added before ignition with a torch. For most of the cases, a small amount of the igniter promoter was used. If the first amount of igniter promoter did not succeed to ignite the oil slick, an increased amount of igniter was used in a second attempt, and so on for a third attempt.

Before conducting an experiment, the air velocity was measured by an anemometer, which measured wind speeds of less than $5 \mathrm{~m} / \mathrm{s}$ (see Table 4 in Section 3.2), which is below the critical operational wind velocity (Buist et al., 2013; Fingas, 2011b; Potter and Buist, 2008).

\subsection{Estimation of parameters}

The herding effectiveness was analysed through the herder capability to thicken the oil slick to a sufficient thickness to attain ignition during the time prior to ignition $(<35 \mathrm{~min})$. Therefore, the measurement of the oil slick thickness during the herding procedure was required. By knowing the initial oil/emulsion weight and the density, the oil slick thickness could readily be estimated using the oil slick area from the recorded images.

During combustion, the properties of the oil and the oil mass will change over time (van Gelderen et al., 2017), and therefore it is impossible to estimate an oil slick thickness. Hence, the herding effectiveness after during burning was analysed through the estimation of the oil slick area along with the area of the oil slick covered by flames.

The burning behaviour of the fresh and weathered crude oils of various sizes was evaluated through two burning-related parameters, the burning efficiency (BE) and the regression rate $\left(\dot{r}^{\prime \prime}\right)$. The first indicates the mass of crude oil burnt during the ISB experiment. Large BE is 
indicative of a significant ratio removal success of spilled crude oil. The burning efficiency can be estimated by using the following expression:

$$
B E[\%]=\frac{m_{0}-m_{f}}{m_{0}} 100
$$

Equation 1

Where $m_{0}$ and $m_{f}$ are the initial mass $[\mathrm{kg}]$ and the final mass of the crude oil, respectively. For the case of emulsified crude oil, only the corresponding oil mass in the emulsion was considered to estimate the BE. For each burning experiment, the post-burnt oil residue was collected in oil-sorbent and hydrophobic pads that were dried out in an industrial oven for 24 hours to remove the excess of water. Thus, the final mass of oil $\left(m_{f}\right)$ was estimated for all experiments.

The second parameter, the burning rate $\left(\dot{r}^{\prime \prime}\right)$, expresses the burning per unit time or thickness deployment in time and it is a useful parameter for in-situ operations. There are various manners to estimate the mass burning rate or regression rate. For this study, the method based on the maximum area coverage was used by applying the following equation (Buist et al., 2011):

$$
\dot{r}^{\prime \prime}[\mathrm{mm} / \mathrm{min}]=\frac{B E * V_{o}}{S_{o i l} A_{f, \max }\left(t_{e x c, 50 \%}-t_{i g, 50 \%}\right)}
$$

Equation 2

Where $V_{o}$ is the initial oil volume [1], $S_{\text {oil }}$ is the oil slick area $\left[\mathrm{m}^{2}\right], A_{f, \max }$ is the maximum percentage coverage of the flame over the oil slick, $t_{\text {exc }, 50 \%}$ is the time when the flame area has decreased to $50 \%$ of the slick area [min], and $t_{i g, 50 \%}$ is the time when $50 \%$ of the slick area is covered by flames [min]. Most of the area and times were obtained from the video recording during the burning experiments.

\section{Results and discussion}

\subsection{Herding effectiveness}

\subsubsection{Herding effectiveness before ignition}

The herding efficiency of OP-40 as a function of time for the different crude oils at various weathering conditions is depicted in Figure 2. The first measurement of the oil slick thickness was taken as the application of the herding agent, and the span of the herding experiments varied from test to test (from 16 to $37 \mathrm{~min}$ ). During each experiment, the herding agent was carefully poured in order to maintain the oil slick located away from the walls. 

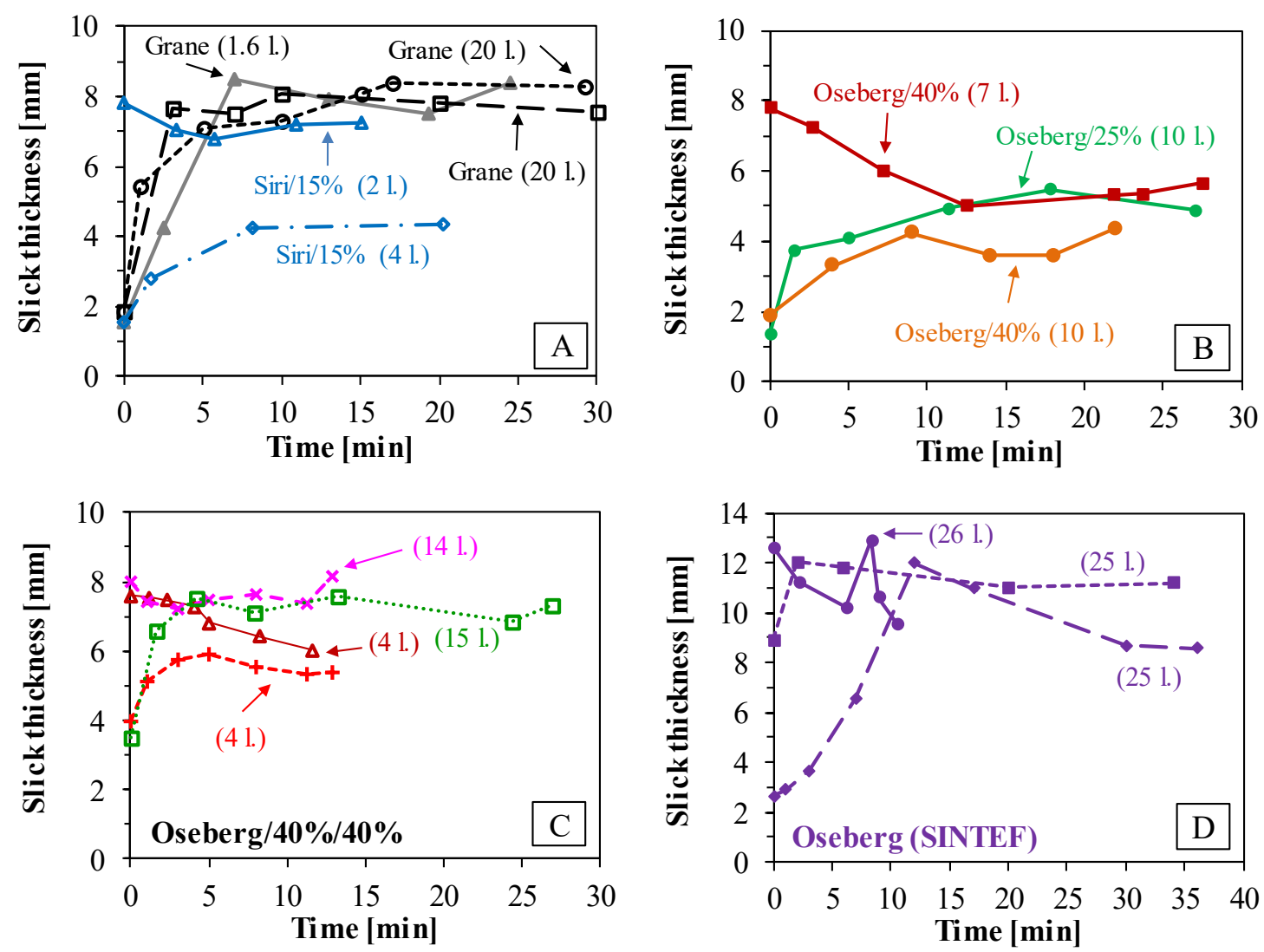

\begin{tabular}{|c|c|c|c|c|c|c|c|c|c|c|c|}
\hline Oil & Symbol & $\begin{array}{l}\text { Herder } \\
\text { treatment }\end{array}$ & $\begin{array}{c}\text { Size } \\
{[1 .]}\end{array}$ & $\begin{array}{c}\text { Evaporation } \\
\text { Degree [\%] }\end{array}$ & $\begin{array}{c}\text { Water } \\
\text { Content } \\
{[\%]}\end{array}$ & Oil & Symbol & $\begin{array}{l}\text { Herder } \\
\text { Treatment }\end{array}$ & $\begin{array}{c}\text { Size } \\
{[1 .]}\end{array}$ & $\begin{array}{l}\text { Evaporation } \\
\text { Degree [\%] }\end{array}$ & $\begin{array}{c}\text { Water } \\
\text { Content } \\
{[\%]}\end{array}$ \\
\hline \multirow{3}{*}{ Grane } & -4 & Post & 1.6 & \multirow{3}{*}{0} & \multirow{3}{*}{0} & \multirow{3}{*}{ Oseberg } & $\rightarrow$ & Post & 10 & 25 & 0 \\
\hline & $-0-$ & Post & 20 & & & & $\rightarrow$ & Pre & 7 & \multirow[b]{2}{*}{40} & \multirow{2}{*}{0} \\
\hline & $-\square-$ & Post & 20 & & & & $\rightarrow$ & Post & 10 & & \\
\hline \multirow{2}{*}{ Siri } & 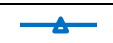 & Pre & 2 & \multirow{2}{*}{15} & \multirow{2}{*}{0} & \multirow{3}{*}{$\begin{array}{l}\text { Oseberg } \\
\text { (SINTEF) }\end{array}$} & $\rightarrow$ & Pre & 26 & \multirow{3}{*}{$>40$} & \multirow{3}{*}{50} \\
\hline & $-\bullet-$ & Post & 4 & & & & $-\infty$ & Post & 25 & & \\
\hline \multirow{4}{*}{ Oseberg } & --+- & Post & 4 & \multirow{4}{*}{40} & \multirow{4}{*}{40} & & $-4--$ & Post & 25 & & \\
\hline & $\triangle$ & Pre & 7.5 & & & & & & & & \\
\hline & $-* x-$ & Pre & 14 & & & & & & & & \\
\hline & …曰... & Post & 15 & & & & & & & & \\
\hline
\end{tabular}

Figure 2 - Oil slick thickness as a function of time for Grane, Siri and Oseberg crude oil under various weathered conditions.

The results corresponding to three experiments with fresh Grane can be seen in Figure 2A. The oil amount was 1.6 litres in one experiment, and 20 litres in the other two. In all the three cases, the herding agent thickened the fresh Grane crude oil slick relatively fast (i.e. within the first five to eight minutes), so that a stable $8 \mathrm{~mm}$ slick thickness was reached. No decay in thickness was observed for the duration of the test. Similar thicknesses or slightly lower thicknesses were reported by Buist et al., who used shallow pans of various sizes (Buist et al., 2017). In their work, they also reported a decay in oil slick thickness for fresh Grane with OP-40. This difference in behaviour might be attributed to the experimental conditions (e.g. indoor lab, extraction, and re-radiation) and the length of the test (60 minutes and longer). The results from Grane are qualitatively similar small-scale experiments reported by Rojas-Alva et al. (RojasAlva et al., 2019a). However, the current Grane results are $2 \mathrm{~mm}$ greater than those reported by Rojas-Alva et al. (Rojas-Alva et al., 2019a), who suggested that the difference was a result of differences in the initial oil slick thickness before herding. In their work, their experiments had an initial oil slickness (after reaching equilibrium) less than $0.5 \mathrm{~mm}$, whereas the initial oil slick thickness was much greater (around $2 \mathrm{~mm}$ ) in the current study. 
The results from the two experiments ( 2 and 4 litres) with Siri crude oil at an evaporated rate of $15 \%$ can also be seen in Figure 2A. In the experiment with 2 litres of oil, the herding agent was applied before the crude oil was poured onto the water basin to minimize the influence of the wind. As a result, the initial thickness of the evaporated Siri for this test was around $8 \mathrm{~mm}$. After a slight decrease in thickness, the oil slick remained constant for the duration of the experiment, which was shorter due to the wind condition. In the experiment with 4 litres of oil, the herding agent was applied following the standard experimental protocol. As seen in Figure $2 \mathrm{~A}$, the oil slick increased in thickness over the first minutes and seemed to remain constant. This difference in oil slick thickness has also been observed by Buist et al. (Buist et al., 2017), and it is hypothesized that when the herder is pre-applied, a thicker oil slick thickness is achieved as more oil gets in contact with the herding agent.

Figure $2 \mathrm{~B}$ depicts the thickening results from $25 \%$ and $40 \%$ evaporated Oseberg blend. The experiment with the $25 \%$ evaporated Oseberg and with the 101 of $40 \%$ evaporated Oseberg show a slightly different behaviour as compared to the experiments with Grane. Oseberg blend has distinct physical and chemical properties, which are further changed due to the weathering process, see Table 3 and Table 4 (Section 2). The wind can also influence the thickening process as observed by the data from the 101 of $40 \%$ evaporated Oseberg blend. The water was pre-treated with OP-40 in the experiment with 10 1. of 40\% evaporated Oseberg, and it was reflected in the thickening behaviour as seen in Figure 2B. This behaviour are comparable with the previous Siri results.

The results of various tests with Oseberg blend at $40 \%$ evaporation degree and $40 \%$ of water content are depicted in Figure $2 \mathrm{C}$. In two tests, the water was pre-treated with the herding agent due to multiple testing. In both experiments (7.5 and 14 1), the initial oil slick thickness was similar (around $8 \mathrm{~mm}$ ). In the experiment with 7.51 , the oil slick suffered a decay over the duration of the test decreasing almost two millimetres in thickness. On the contrary, in the experiment with 14 litres, the oil slick remained steady and even increased slightly. According to the recording, in the second case, the wind seems to have pushed the oil slick against the water basin walls. The normal herding application procedure was followed in the other two tests with the $40 \%$ evaporated and $40 \%$ emulsified Oseberg blend. The weathered oil amounts were 4 and 15 litres, respectively. In both cases, the initial oil slick thickness increased rapidly within the first 5 minutes. After this, a steady oil slick thickness is observed for both tests. However, for the steady period, there is a difference around $2 \mathrm{~mm}$ in thickness for both tests. A noticeable difference was recorded for the wind conditions when both tests were performed, which was stronger in the test with 15 litres.

The results for the strongly emulsified Oseberg blend from SINTEF (more than 40\% evaporation degree and 50\% water content) are depicted in Figure 2D. In the first experiment (circular symbols), the water was pre-treated with the herder due to the wind. The wind also influenced the thickening results as seen in the non-steady behaviour. In the second experiment (square symbols), the oil was poured the standard procedure, but the winds also influenced the thickening result as the oil slick was driven against the basin wall. In the third experiment (rhomboid symbol), the oil was also poured following the standard procedure, and the wind did not affect the thickening as in the previous experiments. The maximum oil slick thickness achieved in the third experiment was the thickest as compared to the previous experiments with less weathered Oseberg blend. Such a discrepancy is attributed to the difference in oil properties between a strongly weathered (evaporated and emulsified) Oseberg blend and an only evaporated Oseberg, see Table 3 (Section 2). The strongly weathered Oseberg blend has a higher viscosity as compared to the less weathered crude oils; thus, it has a higher resistance to spread, and a thicker oil slick thickness would be expected. 
Overall, in all cases, the herding agent OP-40 was capable of thickening the oil slick of the fresh and the weathered crude oils. The herding agent OP-40 was successful in achieving the minimum oil slick thickness $(1 \mathrm{~mm})$ for fresh and weathered crude oil (Buist et al., 2013) needed for a successful ignition. Despite the fact that the wind had an obvious impact on the evolution of the oil slick thickness, the herding agent OP-40 was still capable of performing well in such scenarios. The wind conditions recorded for all tests during the herding experiment are listed in Table 4 in Section 3.2. Additionally, the herding results for the other two tests with $15 \%$ evaporated Siri oil are not presented. During the recording for this experiments, the camera failed to function in one of the tests, and in the other case the camera was not properly located and did not record the experiments.

\subsubsection{Herding effectiveness during burning}

The oil slick areas and the corresponding area of the oil slick covered by the flames for the tests with fresh Grane are depicted in Figure 3. In Figure 3A, the results correspond to the experiment with 1.6 litres of fresh crude Grane. During the herding test, the wind affected the oil slick as this was driven towards the water basin wall where it also remained during the burning experiments. As seen in Figure 3A, after ignition, the initial area of flames remained constant for over 200 seconds. Thereafter, the flames covering the oil slick increased very quickly. At the same time, the oil slick increased in area following the development of the flame from the ignition. After the flames reached a maximum in area coverage over the oil slick, the flames started receding to almost extinguishment. However, the oil slick reduced again in area (and thickness), and the residual flames were capable of re-igniting the remaining oil slick. This process of re-ignition occurred in 5 cycles of 1 minute approximately for the test with 1.61 of fresh crude Grane. After the last cycle, the flames finally extinguished and the oil residue thickened which might indicate the active nature of the monolayer created by the herding agent.

The results for the first test with a larger amount of Grane crude oil, 201 , are depicted in Figure 3B. At the end of the herding experiment and prior to ignition, the oil slick remained centrally located in the water basin. During ignition, the flames (due to the igniter promoter and the gasification of the crude oil) increased in area at a very slow pace for over 100 seconds. Thereafter, the flames travelled in all directions covering the oil slick at a much faster pace. The oil slick also increased in area and showed similar behaviour to the flames. The initial oil slick area increased from $3.95 \mathrm{~m}^{2}$ to a maximum area of $9.6 \mathrm{~m}^{2}$ during 143 seconds. Before reaching the maximum slick area, the oil slick drifted towards the water basin walls and was partly confined. At the maximum oil slick area, the flames started to recede until extinction occurred. In this test, it also seems that the monolayer created by the herding agent seemed to be active and the residual oil slick was re-thickened again after the flame started receding.
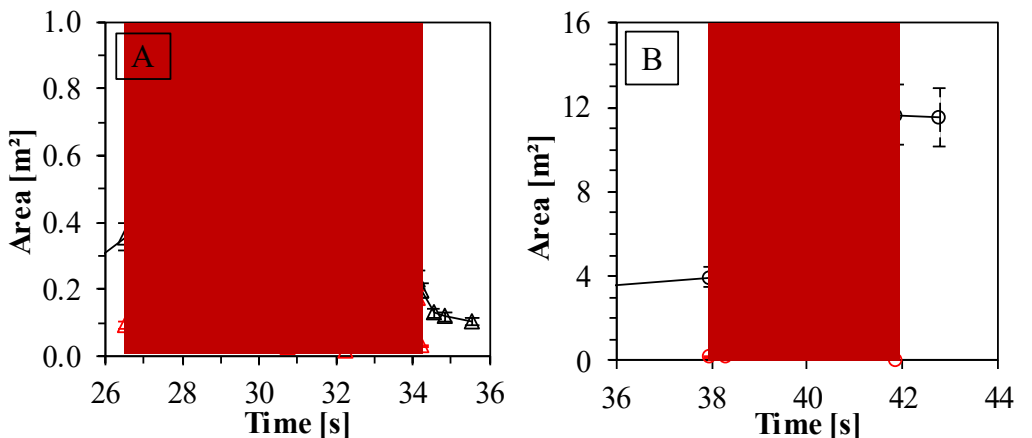

\begin{tabular}{rccccc}
\hline Symbol & Area & Volume [1.] & $\begin{array}{c}\text { Igniter volume } \\
{[\mathrm{ml}]}\end{array}$ & Evap. Rate [\%] & Water content [\%] \\
\hline Oil slick & 1.6 & 20 & 0 & 0 \\
\hline
\end{tabular}




\begin{tabular}{|c|c|c|c|c|c|}
\hline$\vec{\Delta}$ & Flames & & & & \\
\hline 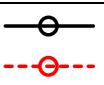 & $\begin{array}{c}\text { Oil slick } \\
\text { Flames }\end{array}$ & 20 & 50 & 0 & 0 \\
\hline
\end{tabular}

Figure 3 - Evolution of the oil slick surface area (black dots) during combustion (shaded area) and the area covered by the flames (red dots). Results from fresh Grane crude oils.

In Figure 4A, the results covering the 2 litres of evaporated Siri crude oils are depicted. After being released onto the water surface, and during herding and burning, the oil slick remained close to the water basin walls. After ignition, the initial oil slick area $\left(0.31 \mathrm{~m}^{2}\right)$ expanded during 73 seconds reaching a maximum area, $1.45 \mathrm{~m}^{2}$. Contrarily to previous tests with fresh Grane, no substantial difference was observed for the development of flames during ignition since flames travelled at the same pace as the slick area from the start of ignition. This might be due to the difference in properties between Siri and Grane. A re-ignition cycle was also observed in this experiment, which is similar to the results with 1.61 . of Grane. After flame extinction, the residual oil slick seemed to have reduced in size slightly as it can be seen in Figure 4A.

In Figure 4B, the results over 40\% evaporated Oseberg are shown. For this experiment, the oil slick drifted towards the water basin wall during herding. After ignition, the flames started travelling at a fast pace and uniformly as in the case with Siri. The initial oil slick area $\left(2.5 \mathrm{~m}^{2}\right)$ increased to a maximum area of $6.8 \mathrm{~m}^{2}$ after 90 seconds. As seen in Figure 4B, the oil slick was not entirely covered by the flames; the recordings show that initially only one part of the oil slick was involved in burning. As the burning progressed, the other oil slick areas were subsequently involved in the overall burning process. It is also noted in Figure 4B that after reaching a maximum in oil slick area, the oil slick seemed to recede slightly and increases again in area. Then, the flames covering the oil slick retreated and extinguished. After the burning period, the residual oil slick was re-thickened as in previous cases.
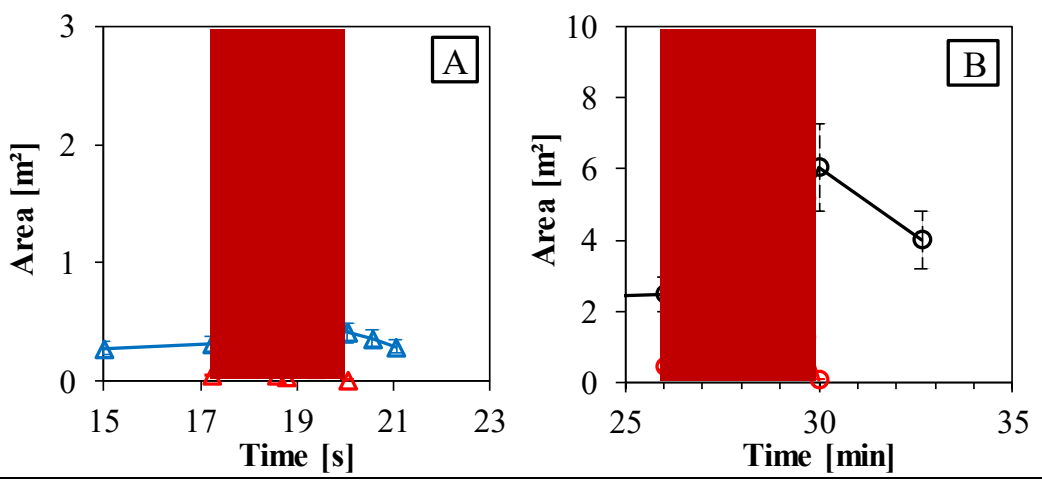

\begin{tabular}{|c|c|c|c|c|c|}
\hline Symbol & Area & Volume [1.] & $\begin{array}{c}\text { Igniter volume } \\
{[\mathrm{ml}]}\end{array}$ & Evap. Rate [\%] & Water content [\%] \\
\hline $\begin{array}{l}\Delta \\
-\Delta-\end{array}$ & $\begin{array}{c}\text { Oil slick } \\
\text { Flames }\end{array}$ & 2 & $x_{2}$ & 15 & 0 \\
\hline $\begin{array}{l}-\theta \\
-\Theta\end{array}$ & $\begin{array}{c}\text { Oil slick } \\
\text { Flames }\end{array}$ & 4 & 5 & 40 & 0 \\
\hline
\end{tabular}

Figure $4-$ Evolution of the oil slick surface area during combustion (shaded area) and the area covered by the flames. Results from evaporated Siri and Oseberg crude oils.

The results over artificially weathered Oseberg blend (evaporated at $40 \%$ and emulsified at $40 \%$ ) for various tests are depicted in Figure 5. In Figure 5A, the results correspond to 41 of weathered Oseberg blend. During herding, the oil slick drifted but remained centrally located in the water basin without touching the walls. However, after ignition, the oil slick continued drifting and reached the water basin walls, where it remained during the entire burning. After ignition, flames slowly developed and there was no substantial increase in flame area during 
the first minute, from which the flames increased at a much faster rate. The oil slick experienced an increase at two paces, similarly as the flames travelled, an initial slow increase and a fast increase. The initial oil slick area, $0.8 \mathrm{~m}^{2}$, increased to a maximum value of $1.9 \mathrm{~m}^{2}$ after 200 seconds. Thereafter, as the flames receded towards extinction, the oil slick reduced in area. The residual oil slick continued thickening even after combustion had finished.

In Figure 5B, the results over the strongly weathered Oseberg blend are depicted. This crude oil was weathered at larger facilities at SINTEF, and therefore it underwent a higher evaporation rate, and its stability was much higher compared to the weathered crudes elaborated in the laboratory, see Table 3 (Section 2). During herding (pre-applied) the oil slick was initially located near the wall of the water basin. Due to the wind, the weathered oil slick drifted and moved towards the opposite wall of the water basin where it remained during ignition. After ignition, the flames covering the oil slick increased slightly for 70 seconds. During this period, the initial oil slick increased proportionally from $4 \mathrm{~m}^{2}$ to $4.5 \mathrm{~m}^{2}$. However, flames did not travel to cover larger areas of the slick as in the previous experiments. Instead, the flames remained where a large amount of the igniter promoter was poured. Then, the flames decreased towards extinguishment. The oil slick suffered an increase in area during this period and even after flame extinguishment. Such behaviour is in contrast to previous experiments where the oil slick was further re-thickened. In this test, a particular sinking behaviour of the oil slick affected by ignition was observed and will be further discussed in Section 3.3.
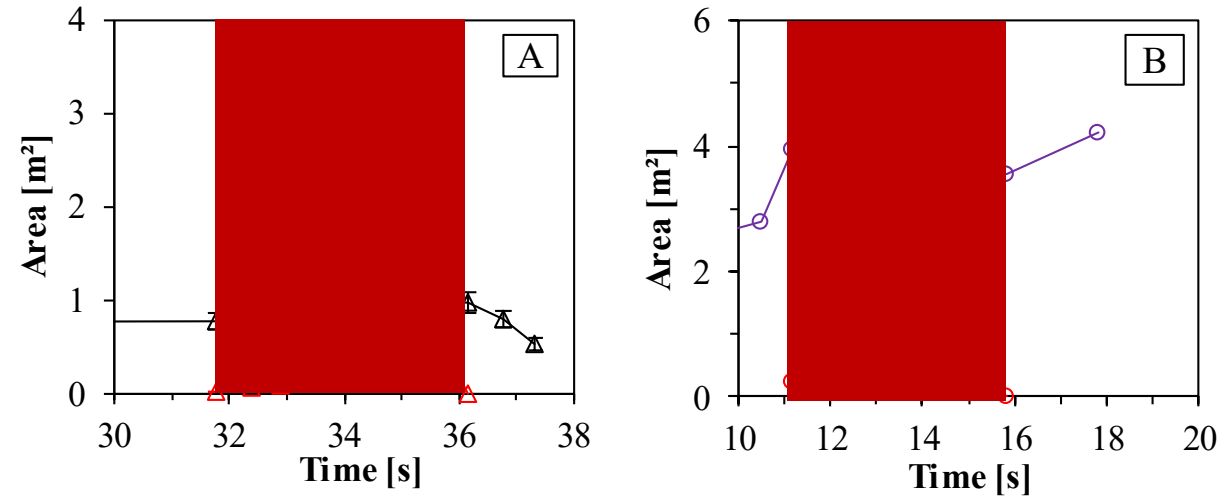

\begin{tabular}{|c|c|c|c|c|c|c|}
\hline Oil & Symbol & Area & Volume [1.] & $\begin{array}{l}\text { Igniter volume } \\
{[\mathrm{ml}]}\end{array}$ & Evap. Rate [\%] & Water content [\%] \\
\hline $\begin{array}{c}\text { Oseberg } \\
\text { blend }\end{array}$ & $\begin{array}{c}\Delta \Delta \\
---\Delta--\end{array}$ & $\begin{array}{l}\text { Oil slick } \\
\text { Flames }\end{array}$ & 4 & 40 & 40 & 40 \\
\hline $\begin{array}{l}\text { Oseberg blend } \\
\text { (SINTEF) }\end{array}$ & $\begin{array}{l}-0 \\
-0\end{array}$ & $\begin{array}{c}\text { Oil slick } \\
\text { Flames }\end{array}$ & 25 & 2000 & $>40$ & 50 \\
\hline
\end{tabular}

Figure 5 - Evolution of the oil slick surface area (black and purple dots) during combustion (shaded area) and the area covered by the flames (red dots) are also represented. The results are from a strongly weathered Oseberg blend.

\subsubsection{Thermal discussion}

During the full combustion process, the vaporization occurs on the own merit of the already established flames. The fuel is heated up due to heat fluxes from the flame (radiation, convection and conduction). Due to intercapillary and buoyancy forces within the crude oil layer and between the crude oil and water layer interface (Farahani et al., 2017), there is a gradient temperature within the oil slick layer in the vertical and horizontal directions. In the latter direction, the flow movements within the oil slick might be more substantial (Farmahini Farahani et al., 2015). Hence, the flame area covering the oil slick increased over time. Also, during burning, the properties of the crude oil are affected (van Gelderen et al., 2017), including the surface tensions. As a consequence, the surface tensions of the crude oil increases counteracting the surface tension from the monolayer created by the herding agent. 
When the oil slick area increases and the slick thickness decreases, there is an increase of the heat losses through the water layer and the temperature of the crude oil is therefore reduced. Hence, there is no enough vaporization rate from the heated crude oil to sustain combustion (the flames recede) and extinction occurs. As the oil temperature decreases, the oil surface tension also decreases to be below than the one from the monolayer created by the herding agent. Such a postulate might partly explain the apparent 're-thickening" behaviour of the oil slick observed when flames started to recede and after flames extinguished.

\subsection{Burning behaviour}

The burning results for all the experiment conducted for this study are listed in Table 4 along with details of the weather conditions and experimental conditions. It seems that the weather conditions somewhat affected the burning efficiency results, but in most of the experiments the obtained burning efficiencies were higher than $50 \%$, similar values were obtained with midsizes of fresh crude oils in (Aggarwal et al., 2017; Buist et al., 2011, 2013). These results indicate the success of the in-situ burning experiments as relatively high burning efficiencies were obtained.

Table 4 - Burning results for all the in-situ burning experiments.

\begin{tabular}{|c|c|c|c|c|c|c|c|c|c|c|c|c|}
\hline Oil type & $\begin{array}{c}\text { Evap. } \\
\text { Degree } \\
{[\%]}\end{array}$ & $\begin{array}{c}\text { Water } \\
\text { content } \\
{[\%]}\end{array}$ & $\begin{array}{c}\text { Volume } \\
\text { oil [1] }\end{array}$ & $\begin{array}{c}\text { Wind } \\
\text { velocity } \\
{[\mathrm{m} / \mathrm{s}]}\end{array}$ & $\begin{array}{l}\mathrm{T}_{\text {water }} \\
{\left[{ }^{\circ} \mathrm{C}\right]}\end{array}$ & $\begin{array}{l}\mathrm{T}_{\text {air }} \\
{\left[{ }^{\circ} \mathrm{C}\right]}\end{array}$ & $\begin{array}{l}\text { Herder } \\
\text { treatment }\end{array}$ & $\begin{array}{c}\text { Slick } \\
\text { thickness } \\
{[\mathrm{mm}]}\end{array}$ & $\begin{array}{c}\emptyset_{\text {equiv }} \\
{[\mathrm{m}]}\end{array}$ & $\begin{array}{c}\text { Igniter } \\
\text { volume } \\
{[\mathrm{ml}]}\end{array}$ & $\begin{array}{l}\mathrm{BE} \\
{[\%]}\end{array}$ & $\begin{array}{c}\dot{r}^{\prime \prime} \\
{[\mathrm{mm} / \mathrm{min}} \\
]\end{array}$ \\
\hline \multirow{3}{*}{ Grane } & 0 & 0 & 1.6 & $0.2-1.8$ & 15 & 24 & Post & 8.4 & & 20 & 75 & - \\
\hline & 0 & 0 & 20 & 1.0 & 5 & 2 & Post & 8.3 & 2.2 & 50 & 78 & 3.5 \\
\hline & 0 & 0 & 20 & 1.5 & 6 & 5.6 & Post & 7.6 & 1.9 & 50 & 72 & 2.4 \\
\hline \multirow{4}{*}{ Siri } & \multirow{4}{*}{15} & \multirow{4}{*}{0} & 2 & $0.2-1.8$ & 15 & 24 & Pre & 7.3 & 0.6 & 3 & 62 & 1.1 \\
\hline & & & 4 & 0.8 & 14 & 28 & Post & 3.8 & & 5 & 66 & - \\
\hline & & & 5 & $0.4-1$ & 12 & 20 & Post & - & & 5 & 70 & - \\
\hline & & & 25 & 0.8 & 14 & 28 & Pre & 4.9 & & 5 & 81 & - \\
\hline \multirow{7}{*}{$\begin{array}{c}\text { Oseberg } \\
\text { blend }\end{array}$} & 25 & 0 & 10 & $0.2-2.5$ & 14.8 & 16 & Post & 4.7 & & 4 & 82 & - \\
\hline & \multirow{6}{*}{40} & \multirow{2}{*}{0} & 7 & $0.2-2.5$ & 14.8 & 16 & Pre & 5.6 & & 4 & 81 & - \\
\hline & & & 10 & 4.2 & 16.7 & 16 & Post & 4.4 & 1.8 & 5 & 70 & 1.2 \\
\hline & & \multirow{4}{*}{40} & 4 & 0.3 & 15 & 22 & Post & 5.4 & 1.0 & 40 & 54 & 3.1 \\
\hline & & & 7.5 & 1 & 14.9 & 15.6 & Pre & 6.0 & 1.3 & 1000 & 60 & 2.4 \\
\hline & & & 14 & 0.3 & 15 & 22 & Pre & 8.2 & 1.5 & 50 & 83 & 3.0 \\
\hline & & & 15 & 3 & 18.2 & 19 & Post & 7.3 & 1.9 & 50 & 75 & 2.7 \\
\hline \multirow{3}{*}{$\begin{array}{l}\text { Oseberg } \\
\text { blend } \\
(\mathrm{NOFO})\end{array}$} & \multirow{3}{*}{$>40$} & \multirow{3}{*}{50} & 26 & $2.4-4.9$ & 11 & 10 & Pre & 11.2 & & 1000 & 12 & - \\
\hline & & & 25 & 3 & 18 & 19 & Post & 9.6 & & 1800 & 7 & - \\
\hline & & & 25 & $1.5-1.9$ & 9.5 & 8.7 & Post & 8.6 & & 2000 & 0 & - \\
\hline
\end{tabular}

As seen in Table 4, very low burning efficiencies were obtained for the strongly weathered Oseberg blend. Despite the fact that the final slick thickness achieved prior to ignition for all tests with the strongly weathered Oseberg blend spanned from 8 to $11 \mathrm{~mm}$. These thicknesses were higher than the minimum oil slick thickness required for a successful ignition for in-situ burning (Buist et al., 2013; Fritt-Rasmussen, 2010). Also, as reported by Fritt-Rasmussen et al. (Brandvik et al., 2010; Fritt-Rasmussen et al., 2012; Fritt-Rasmussen and Brandvik, 2011), strongly weathered crude oils with high content of water are no longer able to sustain ignition. Thus, it can be inferred that the strongly weathered Oseberg is no longer ignitable and cannot sustain flame spread. In the field, crude oil in a similar state would not fulfill the final aim of in-situ burning is to remove as much spilled oil as possible. 
In relation with the regression rate results, the values obtained for some of the experiments vary from 1.1 to $3.5 \mathrm{~mm} / \mathrm{min}$, these results correspond to oil slicks ranging from 0.6 to 2.2 metres in equivalent diameter, see Table 4 . There is no clear correlation of the slick size on the regression rate results for the experiments with fresh crude Grane and artificially weathered Oseberg blend. The results show some variations when comparisons are made for similar tested oil amounts with physical confinement (Fritt-Rasmussen, 2010; Garo et al., 2006; Koseki et al., 1991). Such a discrepancy can be associated with the dynamic confinement process that the oil slicks underwent during burning. These results are however in the same magnitude as regression rates predicted by Buist et al. (Buist et al., 2013) for fresh crude oils and weathered crude oils, although those predictions are for ISB diameters greater than $3.5 \mathrm{~m}$. Similarly, results from other experimental studies (Fritt-Rasmussen, 2010; Garo et al., 2006; Koseki et al., 1991) show the same order of magnitude compared to the regression rates obtained in this study.

\subsubsection{Scalability of BE results}

The burning efficiency results as a function of the initial oil or emulsion amount are depicted in Figure 6. For two weathered oils, the burning efficiency seems to scale as the oil amount increases as shown by the trend lines. Nonetheless, the same cannot be said for Grane crude oil and the evaporated Oseberg, where no scaling is observed. In this case, it can be presumed that the water basin wall affected the burning process positively. In the previous sections, it was shown that in the experiment with 1.6 litres of Grane, re-ignited multiple times leading to a high burning efficiency. In the case of the $40 \%$ evaporated Oseberg, the main difference between the two experiments with 7 and 10 litres is the wind. In the experiment with 10 litres, the wind was measured at $4.2 \mathrm{~m} / \mathrm{s}$, which can have had a negative effect on the combustion process as it might have reduced the gasification concentration on the fuel surface, and at the same time removing heat from the combustion zone (Hu, 2017).

The scaling for the fresh crude and weathered crude oils is however clear for the evaporated Siri and the weathered Oseberg blend (evaporated and emulsified). There are no physical methods or any scaling approach with a relation to fully explain how the burning efficiency scales up with the increasing amount of oil. Drawing such a correlation would have practical meaning for the in-situ burning of crude oil as a cleaning method. Based on small-scale data (including thermal and time length scales and the properties of the crude oil) the final burning efficiency of a large amount of crude oil could be potentially estimated.

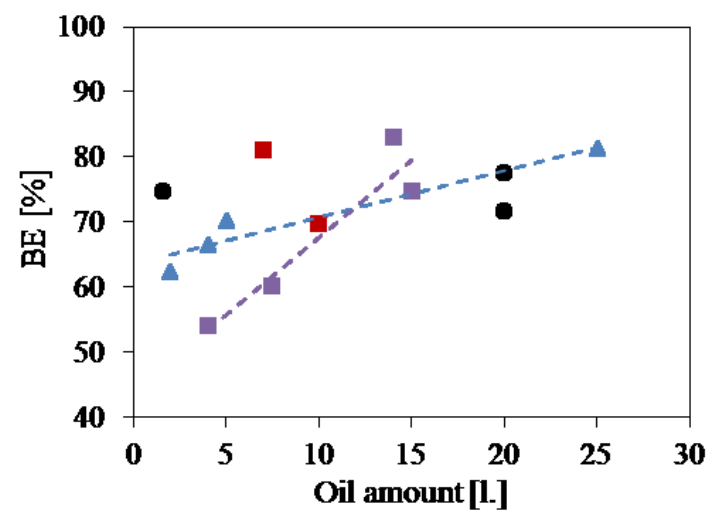

\begin{tabular}{|c|c|c|c|}
\hline Oil & Symbol & $\begin{array}{c}\text { Evap. } \\
\text { Degree } \\
{[\%]}\end{array}$ & $\begin{array}{c}\text { Water } \\
\text { content } \\
{[\%]}\end{array}$ \\
\hline Grane & 0 & 0 & 0 \\
\hline Siri & $\Delta$ & 15 & 0 \\
\hline Oseberg & $\mathbf{0}$ & 40 & 0 \\
\hline blend & 口 & 40 & 40 \\
\hline
\end{tabular}


Figure 6 - Burning efficiency as a function of the fuel amount for Siri, Grane and Oseberg crude oils under various weathered conditions.

\subsubsection{Comparison with other studies}

Burning efficiency results from other studies with fresh crude weathered crude oils (Aggarwal et al., 2017; Buist et al., 2017; Buist and Meyer, 2012; Bullock et al., 2017; Potter et al., 2016; Rojas-Alva et al., 2019b; Rojas Alva et al., 2018; S.L. Ross Environmental Research Ltd., 2012; van Gelderen et al., 2016) along with the current results are depicted in Figure 7. In all results, OP-40 herding agent was used to confining the crude oils chemically. As seen in Figure 7 , there is a clear scaling dependency between small amounts of crude oil and large amounts with a scattering of data. The comparison of the results from various studies does not take into account other variables inferred from the experimental conditions and procedures for each study, see the legend in Figure 7. The wind will affect the feedback mechanisms, fuel-air mixing and the boundary layer in the diffusive combustion process (Hu, 2017). Hence, it is expected that substantial variability will be observed.

The physical explanation behind such a scaling observed in Figure 6 and Figure 7 lies on the heat feedback mechanisms (conductive, convective and radiative) and the heat balance at the fuel surface during burning. It is expected that the energy received at the fuel surface (to vaporize enough gases) differs from small-scale to large-scale and it increases as the size of the oil slick increases. As the size of the oil slick increases, the role of the heat feedback mechanisms will change, in a small pool fire conduction from the gas-phase to the condensedphase dominates the heat feedback. In large pool fires, the radiative feedback contributes largely to the heat balance at the fuel surface (Blinov and Khudyakov, 1961).

The scaling observed in Figure 7 differs qualitatively with the regimes reported in physically confined experiments (Rojas-Alva et al., 2019b). Two distinctive regimes of the BE as a function of the oil size and with less dispensability are reported in (Rojas-Alva et al., 2019b). In addition, the regression rate results from experimental studies show a scaling with two regimes as a function of the oil size (Blinov and Khudyakov, 1961; Garo et al., 2007, 2006; Koseki et al., 1991; Rojas-Alva et al., 2019b), in these experimental studies the crude oil was confined during the burning. Chemically confined oil slick during in-situ burning face another complication which is related to the dynamic behaviour of the oil slick as this expands in area (decreases in thickness) over time. In these situations, the regression rates and burning efficiencies will consequently carry such variability, as shown in the scattering in Figure 7.

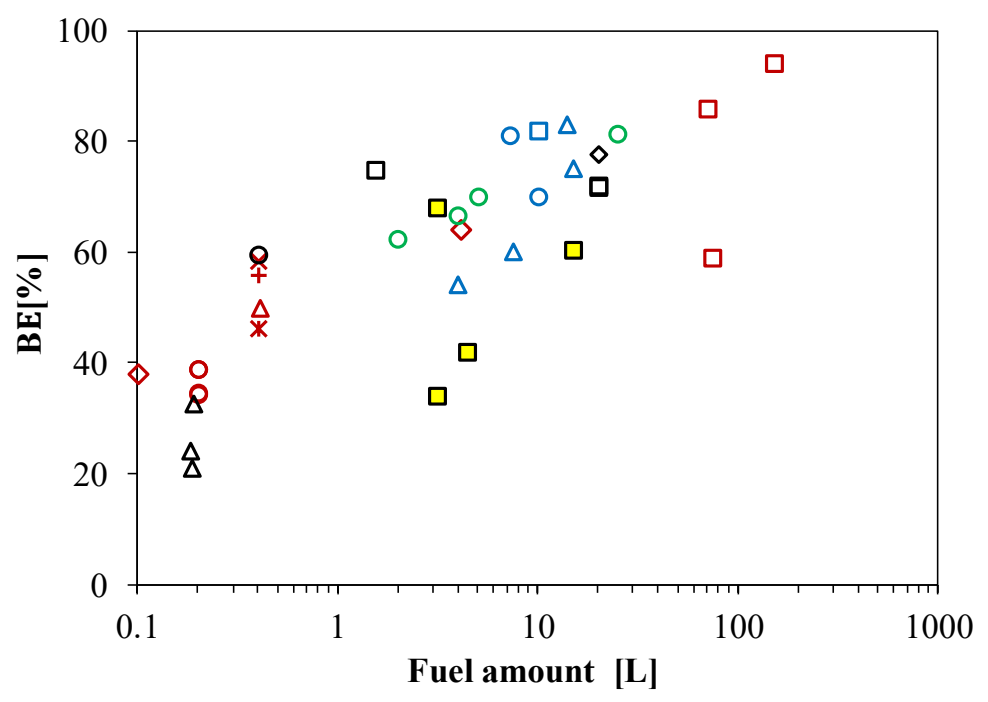




\begin{tabular}{|c|c|c|c|c|c|c|c|c|c|c|c|c|c|c|c|}
\hline Oil & $\begin{array}{l}\text { ठे } \\
\text { ह્ડ }\end{array}$ & $\begin{array}{c}\text { Evap. } \\
\text { Degree } \\
{[\%]}\end{array}$ & $\begin{array}{c}\text { Water } \\
\text { content } \\
{[\%]}\end{array}$ & $\begin{array}{l}\text { Wind } \\
{[\mathrm{m} / \mathrm{s}]}\end{array}$ & $\begin{array}{c}\text { Ice } \\
\text { coverage } \\
{[\%]}\end{array}$ & $\begin{array}{l}\text { Rig } \\
\text { Size } \\
{\left[\mathrm{m}^{2}\right]}\end{array}$ & Ref. & Oil & $\begin{array}{l}\text { ठे } \\
\text { है } \\
\text { है }\end{array}$ & $\begin{array}{c}\text { Evap. } \\
\text { Degree } \\
{[\%]}\end{array}$ & $\begin{array}{c}\text { Water } \\
\text { content } \\
{[\%]}\end{array}$ & $\begin{array}{l}\text { Wind } \\
{[\mathrm{m} / \mathrm{s}]}\end{array}$ & $\begin{array}{c}\text { Ice } \\
\text { coverage } \\
{[\%]}\end{array}$ & $\begin{array}{l}\text { Rig } \\
\text { Size } \\
{\left[\mathrm{m}^{2}\right]}\end{array}$ & Ref. \\
\hline \multirow{7}{*}{ 足 } & 0 & 0 & 0 & No & 0 & 1 & $\begin{array}{c}\text { (Rojas-Alva et } \\
\text { al., 2019b) }\end{array}$ & \multirow{4}{*}{ Grane } & $\Delta$ & 0 & 0 & No & 0 & 1 & $\begin{array}{c}\text { (Rojas- } \\
\text { Alva et al., } \\
\text { 2019b) }\end{array}$ \\
\hline & $\Delta$ & 0 & 0 & 0 & 0 & 12 & $\begin{array}{c}\text { (Buist and Meyer, } \\
2012 \text { ) } \\
\end{array}$ & & 0 & 0 & 0 & No & 0 & $\begin{array}{c}1 \\
\& 12 \\
\end{array}$ & $\begin{array}{r}\text { (Buist et } \\
\text { al., 2017) } \\
\end{array}$ \\
\hline & $\square$ & 0 & 0 & NS & 10 & 1800 & $\begin{array}{r}\text { (Aggarwal et al., } \\
2017)\end{array}$ & & $\diamond$ & 0 & 0 & $<1$ & 0 & 20 & $\begin{array}{c}\text { (Rojas } \\
\text { Alva et al., } \\
\text { 2018) }\end{array}$ \\
\hline & $\diamond$ & 0 & 0 & $<2$ & 0 & $\begin{array}{c}0.1 \& \\
9\end{array}$ & $\begin{array}{c}\text { (Bullock et al., } \\
\text { 2017) }\end{array}$ & & $\square$ & 0 & 0 & $<1.8$ & 0 & 20 & Current \\
\hline & $x$ & 0 & 0 & 0 & 0 & \multirow{3}{*}{12.1} & \multirow{3}{*}{$\begin{array}{l}\text { (Buist et al., } \\
\text { 2017) }\end{array}$} & \multirow{3}{*}{$\begin{array}{l}\text { Oseberg } \\
\text { Blend }\end{array}$} & $\square$ & 25 & 0 & $<2.5$ & 0 & \multirow{3}{*}{20} & \multirow{3}{*}{ Current } \\
\hline & * & 20 & 0 & 0 & 0 & & & & 0 & 40 & 0 & $<4.2$ & 0 & & \\
\hline & + & 27 & 0 & 0 & 0 & & & & $\Delta$ & 40 & 40 & $<3$ & 0 & & \\
\hline DUC & 口 & 0 & 0 & $<6$ & $<25$ & 1 & $\begin{array}{c}\text { (van Gelderen et } \\
\text { al., 2016) }\end{array}$ & Siri & 0 & 15 & 0 & $<1.8$ & 0 & 20 & Current \\
\hline
\end{tabular}

Figure 7 - Burning efficiency (BE) as a function of the initial oil amount. Current results and results from other studies (Aggarwal et al., 2017; Buist et al., 2017; Buist and Meyer, 2012; Bullock et al., 2017; Potter et al., 2016; Rojas-Alva et al., 2019b; Rojas Alva et al., 2018; S.L. Ross Environmental Research Ltd., 2012; van Gelderen et al., 2016) are presented, and the OP40 herder was used for all the experiments.

\subsection{The behaviour of post-burn residues}

The sinking behaviour of post-burn residues has not been quantified concerning the overall amount of burnt oil in previous studies in mid to large-scale experiments, with the exception of Deepwater Horizon (Stout and Payne, 2016). However, there are a few studies based on small-scale experimental work where the properties of the in-situ burn residues were investigated (Buist et al., 1997, 2013; Fritt-Rasmussen et al., 2013). In mid-scale and largescale experiments, quantification of virtually all the sinking post-burn residues can be challenging as it would require underwater imaging and large trapping mechanisms to be installed underneath the fuel/water interface or on the seabed. In open waters, such a task is extremely difficult and often not efficient (Michel and Hansen, 2017; Scholz et al., 2004). In this study, in some of the experiments, especially those with strongly weathered crude oils, the partial or full sinking of the post-burn residues was observed.

In two tests, the sunken post-burn residues were retrieved by using fine-meshed pond skimmer. The sunken residue was then collected with sorbent pads to be dried out along with other post burn residue. The subsequent part that corresponds to the sunken oil residue was estimated concerning the initial oil amount; hereafter referred to as the sunken percentage. Table 5 lists the experiments where the sinking of post-burn residues was observed, only in two experiments was it possible to quantify the amount of sunken residues with respect to the initial amount of crude oil. In the rest of the experiment listed, full sinking or partial sinking of the post-burn residues was observed. Similar behaviour of the partial sinking was observed during the Deepwater horizon burn tests (Shigenaka et al., 2015).

The post-burn residue sinks due to various variables: residue density, incorporation of sand grains, residue temperature, seawater temperature, and seawater density (Scholz et al., 2004). For the current study, it seems that the most likely explanation is that the residue density is higher than the water density. The density of the post-burn residue increases as its temperature cools down. For the two experiments ( $40 \%$ evaporation degree and $40 \%$ water content) where the sinking of the residues was quantified, there seems to be a slight difference in sunken 
percentage, see Table 5. The experiment with 7.5 litres of weathered Oseberg resulted in a $60 \%$ burning efficiency and a 1.4 sunken percentage, whereas the experiment with 15 litres of the same weathered oil resulted in a higher burning efficiency (75\%) and slightly higher sunken percentage (3.2). It is difficult to draw a conclusion based on a few experimental points, but it might be plausible that higher burning efficiency will result in a higher sunken percentage. Previous studies have shown that experiments with higher burning efficiencies correlate to burn residues with larger densities (Buist et al., 1997).

There is no strong evidence that sunken burn residues pose an acute toxic risk to biota (Buist et al., 2013; Fritt-Rasmussen et al., 2015). However, there are major concerns of the sunken burn residue's effect (smothering and coating) on benthic organisms and habitats on the seafloor (Fritt-Rasmussen et al., 2015; Scholz et al., 2004). As pointed out by Fritt-Rasmussen and co-workers (Fritt-Rasmussen et al., 2015), the amount of research on the characterisation of the burn residues is limited. The Deepwater Horizon burns have shown that large quantities of the post-burn residue can sink to the seafloor (Shigenaka et al., 2015; Stout and Payne, 2016). The impact of sunken burn residues of weathered crude oils has not been addressed in previous literature, to the knowledge of the authors.

The composition of the post-burn residue was not measured as it was beyond the scope of the current study. As the weathered oil slick burns, it breaks leaving an emulsion layer in the bottom, and on top, a crude oil layer is vaporizing to sustain combustion, as hypothesized by Walavalkar and Kulkarni (Walavalkar and Kulkarni, 2001). According to Van Gelderen et al. (van Gelderen et al., 2017), the properties of the crude oil will change throughout the burning time, as the oil layer vaporizes the various components of the crude oil (from light to heavy). The light components will vaporize first leaving the heavier components behind. Thus the density of the crude oil increases as the burning progresses. Furthermore, the emulsion layer might also increase in density as it breaks into fuel and an emulsified layer, leading to an increase in the proportion of water in the post-burn sinking residue. However, more detail experiments with sinking residues are required to study this sinking behaviour.

Table 5 - Post-burn residue quantification and observation.

\begin{tabular}{|c|c|c|c|c|c|}
\hline Oil & $\begin{array}{c}\text { Evaporation } \\
\text { Degree [\%] }\end{array}$ & $\begin{array}{c}\text { Emulsification } \\
\text { Degree [\%] }\end{array}$ & $\begin{array}{c}\text { Oil } \\
\text { amount } \\
{[1]}\end{array}$ & $\begin{array}{l}\mathrm{BE} \\
{[\%]}\end{array}$ & $\begin{array}{c}\text { Sunken } \\
\text { percentage } \\
{[\%]}\end{array}$ \\
\hline \multirow{4}{*}{ Oseberg blend } & \multirow{4}{*}{40} & \multirow{4}{*}{40} & 4 & 54 & $*$ \\
\hline & & & 7.5 & 60 & 1.4 \\
\hline & & & 14 & 83 & $*$ \\
\hline & & & 15 & 75 & 3.2 \\
\hline \multirow{3}{*}{$\begin{array}{l}\text { Oseberg blend } \\
\text { (NOFO) }\end{array}$} & \multirow{3}{*}{$>40$} & \multirow{3}{*}{50} & 25 & 0 & $*$ \\
\hline & & & 25 & 12 & $*$ \\
\hline & & & 25 & 7 & $*$ \\
\hline
\end{tabular}

*Full or partial sinking of post-burn residues was observed.

\section{Conclusions}

In all experiments, the chemical herding agent (OP-40) could thicken and confine all fresh and weathered crude oils, and the theoretical minimum oil slick thickness $(1 \mathrm{~mm})$ to sustain ignition 
and flame spread was achieved. In some of the experiments, the water was pre-treated with herder; hence, the herding effectiveness results should not directly be extrapolated to real cases; these results are illustrative and used for comparison. The thickening behaviour of the herder was found to depend on the oil type and weathering degree of the oil. During burning, the ability of the surface monolayer created by the herding agent to thicken the oil diminished, but after extinction occurred, the residual oil slick was re-thickened. It seems that the surface monolayer is still active after being exposed to radiation from the flames. Further research is required to elucidate the fate of the herder agent after in-situ burning experiments.

Ignition and subsequent flame spread were successfully achieved in all experiments; the exception was the strongly weathered Oseberg with the highest water content. The burning efficiency results together with results from other studies (same herding agent) showed that the burning efficiency scaled with the oil slick size (in volume). However, the scaling is qualitatively different from ISB results with physical confinement reported in the literature.

The sinking behaviour was observed to happen partially (residues remained below the water level) or fully (residues sank to the bottom of the water tank) in the experiments with weathered crude oils. The post-burn sinking residues were quantified concerning the initial oil amount in two experiments. Further studies on the quantification of the burn residue as a function of the weathered level of the crude requires further attention, as it might help in the full characterization of sunken burn residues.

The results presented in the current study indicate that ISB of chemically weathered crude oils may be feasible in real scenarios. However, more work is needed to fully characterise the dynamic behaviour of the herded oil slick during burning. Also, the scaling dependencies and sinking behaviour also need further attention. Scaling relations should be developed to predict the burning efficiency of realistic scenarios based on small-scale testing. The current study will hopefully encourage future investigations to continue working on these gaps.

\section{Acknowledgment}

The authors would like to thank NOFO for the financial support, DESMI for good discussions, and SINTEF for providing the weathered crude oil. The authors are especially thankful to Nordsjælland Brandskole for the support related to the mid-scale experiments. 


\section{References}

Aggarwal, S., Schnabel, W., Buist, I., Garron, J., Bullock, R., Perkins, R., Potter, S., Cooper, D., 2017. Aerial application of herding agents to advance in-situ burning for oil spill response in the Arctic: A pilot study. Cold Reg. Sci. Technol. 135, 97-104.

Aksenov, Y., Popova, E.E., Yool, A., Nurser, A.J.G., Williams, T.D., Bertino, L., Bergh, J., 2017. On the future navigability of Arctic sea routes: High-resolution projections of the Arctic Ocean and sea ice. Mar. Policy 75, 300-317. https://doi.org/10.1016/J.MARPOL.2015.12.027

Bech, C., Sveum, P., Buist, I., 1992. In-situ burning of emulsions: the effect of varying water content and degree of evaporation, in: Proceedings 15th AMOP Technical Seminar. pp. 547-559).

Blinov, V.I., Khudyakov, G.N., 1961. Diffusion burning of liquids. https://doi.org/AERDL-T-1490-A

Brandvik, P.J., Faksness, L.-G., 2009. Weathering processes in Arctic oil spills : Meso-scale experiments with different ice conditions. Cold Reg. Sci. Technol. 55, 160-166. https://doi.org/10.1016/j.coldregions.2008.06.006

Brandvik, P.J., Fritt-Rasmussen, J., Daniloff, R., Leirvik, F., 2010. Using a Small Scale Laboratory Burning Cell to Measure Ignitability for In Situ Burning of Oil Spills as a Function of Weathering, in: Thirty-Third AMOP Technical Seminar on Environmental Contamination and Response. Environment Canada, Halifax, Nova Scotia, Canada, pp. 755-771.

Brogaard, N., Sørensen, M., Fritt-Rasmussen, J., Rangwala, A., Jomaas, G., 2014. A new Experimental Rig for Oil Burning on Water-Results for Crude and Pure Oils. Fire Saf. Sci. 11, $1481-1495$.

Buist, I., 2006. Mid-scale test tank research on using oil herding surfactants to thicken oil slicks in pack ice: An update, in: Environment Canada Arctic and Marine Oil Spill Program Technical Seminar (AMOP) Proceedings. Environment Canada, Vancouver, BC, Canada, pp. 691-709.

Buist, I., Canevari, G., Nedwed, T., 2009. New Herding Agents for Thickening Oil Slicks in Drift Ice for In Situ Burning, in: Proceedings of the 33th AMOP Technical Seminar on Environmental Contamination and Response. Environment Canada, Halifax, Nova Scotia, Canada.

Buist, I., Cooper, D., Trudel, K., Fritt-Rasmussen, J., Wegeberg, S., Gustavson, K., Lassen, P., Rojas Alva, W.U., Zabilansky, L., 2017. Research investigations into herder fate, effects and windowsof-opportunity, International Association of Oil \& Gas Producers.

Buist, I., Glover, N., 1995. In situ burning of Alaska North Slope emulsions, in: Ray, J.P. (Ed.), International Oil Spill Conference. Elsevier Ltd, Long Beach, California (US), pp. 139-146.

Buist, I., Meyer, P., 2012. Research on Using Oil Herding Agents for Rapid Response In Situ Burning of Oil Slicks on Open Water, in: Proceedings of the 35th AMOP Technical Seminar on Environmental Contamination and Response.

Buist, I., Potter, S., 2010. Barents Sea Field Test of Herder to Thicken Oil for In situ Burning in Drift Ice, in: Proceedings of the Thirty-Third AMOP Technical Seminar on Environmental Contamination and Response. Environment Canada, Ottawa, Ontario, pp. 725-742.

Buist, I., Potter, S., Belore, R., 2010. Employing Chemical Herders to Improve Marine Oil Spill Response Operations, in: Thirty-Third AMOP Technical Seminar on Environmental Contamination and Response. Halifax, Nova Scotia, Canada, pp. 1109-1134.

Buist, I., Potter, S., Nedwed, T., Mullin, J., 2011. Herding surfactants to contract and thicken oil spills in pack ice for in situ burning. Cold Reg. Sci. Technol. 67, 3-23.

https://doi.org/10.1016/j.coldregions.2011.02.004

Buist, I., Potter, S., Nedwed, T., Mullin, J., 2008a. Herding Agents Thicken Oil Spills in Drift Ice to 
Facilitate In Situ Burning: A new Trick for an Old Dog, in: International Oil Spill Conference. American Petroleum Institute, pp. 673-679.

Buist, I., Potter, S., Nedwed, T., Mullin, J., 2007. Field research on using oil herding surfactants to thicken oil slicks in pack ice for in situ burning, in: Arctic and Marine Oilspill Program (AMOP) Technical Seminar. Environment Canada, Edmonton, Canada, p. 403.

Buist, I., Trudel, K., Morrison, J., Environmental, S.L.R., Aurand, D., Light, B., 1997. Laboratory studies of the properties of In-situ burn residues, in: International Oil Spill Conference. American Petroleum Institute, Edmonton, Canada, pp. 149-156.

Buist, I., Zabilansky, L., Guarino, A., Mullin, J., 2008b. Recent mid-scale research on using oil herding surfactants to thicken oil slicks in pack ice for In Situ burning. Oil Spill Response A Glob. Perspect.

Buist, I.A., Potter, S.G., Trudel, B.K., Shelnutt, S.R., Walker, A.H., Scholz, D.K., Brandvik, P.J., Fritt-Rasmussen, J., Allen, A.A., Smith, P., 2013. In Situ Burning in Ice-affected waters: State of Knowledge report.

Buist, I.A., Twardus, E.M., 1985. Burning Unconfined Oil Slicks: Large Scale Tests and Modelling, in: Proceedings of the 8th Annual Arctic Marine Oilspill Program Technical Seminar. Environment Canada, Ottawa, Canada, pp. 103-130.

Bullock, R.J., Aggarwal, S., Perkins, R.A., Schnabel, W., 2017. Scale-up considerations for surface collecting agent assisted in-situ burn crude oil spill response experiments in the Arctic: Laboratory to field-scale investigations. J. Environ. Manage. 190, 266-273. https://doi.org/10.1016/j.jenvman.2016.12.044

Bullock, R.J., Perkins, R.A., Aggarwal, S., 2019. In-situ burning with chemical herders for arctic oil spill response: meta-analysis and review. Sci. Total Environ. 8, 55.

Dickins, D., Brandvik, P.J., Bradford, J., Faksness, L., Liberty, L., Daniloff, R., 2008. Svalbard 2006 Experimental Oil Spill Under Ice: Remote Sensing, Oil Weathering Under Arctic Conditions and Assessment of Oil Removal By in-Situ Burning. Int. Oil Spill Conf. Proc. 2008, 681-688. https://doi.org/10.7901/2169-3358-2008-1-681

Energetex Engineering, 1981. Burning of Crude Oil under Wind Herding Conditions. Energetex Engineering, Waterloo, Ontario.

Evans, D.D., George, W., Baum, H.R., Walton, W.D., Kevin, B., 2001. In Situ Burning of Oil Spills. J. Res. Natl. Inst. Stand. Technol. 106, 231-278.

ExxonMobil, 2018. Oseberg Blend [WWW Document]. Crude oils. URL http://corporate.exxonmobil.com/en/company/worldwide-operations/crude-oils/oseberg-blend (accessed 7.1.19).

Farahani, H., Alva, W.U.R., Rangwala, A.S., Jomaas, G., 2017. Convection-driven melting in an noctane pool fire bounded by an ice wall. Combust. Flame 179, 219-227. https://doi.org/10.1016/j.combustflame.2017.02.006

Farmahini Farahani, H., Jomaas, G., Rangwala, A.S., 2015. Effects of convective motion in n-octane pool fires in an ice cavity. Combust. Flame 162, 4643-4648. https://doi.org/10.1016/j.combustflame.2015.09.021

Filler, D.M., Kennicutt, M.C., Snape, I., Sweet, S.T., Klein, A.G., 2015. Arctic and Antarctic Spills, in: Fingas, M. (Ed.), Handbook of Oil Spill Science and Technology. John Wiley \& Sons.

Fingas, M., 2011a. Physical Spill Countermeasures, in: Fingas, Mervin (Ed.), Oil Spill Science and Technology. Elsevier Inc., pp. 303-337. https://doi.org/10.1016/B978-1-85617-943-0.10012-7

Fingas, M., 2011b. Weather Effects on Oil Spill Countermeasures, in: Fingas, Mervin (Ed.), Oil Spill 
Science and Technology. Elsevier Inc., pp. 339-426. https://doi.org/10.1016/B978-1-85617-9430.10013-9

Fingas, M., Fieldhouse, B., 2015. Water-in-oil Emulsions: Formation and Prediction, in: Fingas, Mervin (Ed.), Handbook of Oil Spill Science and Technology,. John Wiley \& Sons, pp. 225270. https://doi.org/10.1002/9781118989982

Fingas, M.F., Halley, G., Ackerman, F., Nelson, R., Bissonnette, M., Laroche, N., Wang, Z., Lambert, P., Li, K., Jokuty, P., Sergy, G., Tennyson, E.J., Mullin, J., Hannon, L., Halley, W., Latour, J., Galarneau, R., Ryan, B., Turpin, R., Campagna, P., Aurand, D. V., Hiltabrand, R.R., 1995. The Newfoundland Offshore Burn Experiment-Nobe, in: International Oil Spill Conference Proceedings. pp. 123-132. https://doi.org/10.7901/2169-3358-1995-1-123

Fritt-Rasmussen, J., 2010. In situ burning of Arctic marine oil spills - Ignitability of various oil types weathered at different ice conditions. A combined laboratory and field study (PhD Dissertation). Technical University of Denmark.

Fritt-Rasmussen, J., Ascanius, B.E., Brandvik, P.J., Villumsen, A., Stenby, E.H., 2013. Composition of in situ burn residue as a function of weathering conditions. Mar. Pollut. Bull. 67, 75-81. https://doi.org/10.1016/j.marpolbul.2012.11.034

Fritt-Rasmussen, J., Brandvik, P.J., 2011. Measuring ignitability for in situ burning of oil spills weathered under Arctic conditions: From laboratory studies to large-scale field experiments. Mar. Pollut. Bull. 62, 1780-1785. https://doi.org/10.1016/j.marpolbul.2011.05.020

Fritt-Rasmussen, J., Brandvik, P.J., Villumsen, A., Stenby, E.H., 2012. Comparing ignitability for in situ burning of oil spills for an asphaltenic, a waxy and a light crude oil as a function of weathering conditions under arctic conditions. Cold Reg. Sci. Technol. 72, 1-6. https://doi.org/10.1016/j.coldregions.2011.12.001

Fritt-Rasmussen, J., Wegeberg, S., Gustavson, K., 2015. Review on Burn Residues from in Situ Burning of Oil Spills in Relation to Arctic Waters. Water. Air. Soil Pollut. 226. https://doi.org/10.1007/s11270-015-2593-1

Garo, J.-P., Koseki, H., Vantelon, J.-P., Fernandez-Pello, C., 2007. Combustion of liquid fuels floating on water. Therm. Sci. 11, 119-140. https://doi.org/10.2298/TSCI0702119G

Garo, J.P., Vantelon, J.P., Koseki, H., 2006. Thin-Layer Boilover: Prediction of Its Onset and Intensity. Combust. Sci. Technol. 178, 1217-1235. https://doi.org/10.1080/00102200500296846

Garo, J.P., Vantelon, J.P., Souil, J.M., Breillat, C., 2004. Burning of weathering and emulsified oil spills 28, 753-761. https://doi.org/10.1016/j.expthermflusci.2003.12.013

Guénette, C.C., Sveum, P., Bech, C.M., Buist, I.A., 1995. Studies of in situ burning of emulsions in norway, in: International Oil Spill Conference. American Petroleum Insitute, Long Beach, California (US), pp. 115-122.

Hu, L., 2017. A review of physics and correlations of pool fire behaviour in wind and future challenges. Fire Saf. J. 91, 41-55. https://doi.org/10.1016/j.firesaf.2017.05.008

Koseki, H., Kokkala, M., Mulholland, G., 1991. Experimental Study Of Boilover In Crude Oil Fires. Fire Saf. Sci. 3, 865-874. https://doi.org/10.3801/IAFSS.FSS.3-865

Kunieda, H., Uddin, M.H., Furukawa, H., Harashima, A., 2001. Phase Behavior of a Mixture of Poly(oxyethylene)-Poly(dimethylsiloxane) Copolymer and Nonionic Surfactant in Water. Macromolecules 34, 9093-9099. https://doi.org/10.1021/ma011199i

Lane, P., Newsom, P., Buist, I., Nedwed, T., Tidwell, A., Flagg, K., 2012. Recent efforts to develop and commercialize oil herders, in: 35th AMOP Technical Seminar on Environmental Contamination and Response. Vancouver, BC, Canada, pp. 472-479. 
Michel, J., Hansen, K.A., 2017. Sunken and Submerged Oil, in: Fingas, M. (Ed.), Oil Spill Science and Technology. Elsevier Inc., pp. 731-758. https://doi.org/https://doi.org/10.1016/B978-0-12809413-6.00013-8

Nedwed, T., Tidwell, A., Buist, I., Belore, R., Canevari, G., 2012. Advances in treating agents for oil spill reponse, in: SPE/APPEA International Conference on Health, Safety, and Environment in Oil and Gas Exploration and Production. Society of Petroleum Engineers, Perth, Australia.

Nordvik, A.B., Champ, M.A., Bitting, K.R., 2003. Estimating Time Windows for Burning Oil at Sea: Processes and Factors. Spill Sci. Technol. Bull. 8, 347-359. https://doi.org/10.1016/S13532561(03)00097-5

Nuka, Research \& Planning Group, L., 2010. Oil spill prevention and response in the U.S. Arctic Ocean: Unexamined Risks, Unacceptable Consequences. Washington, DC.

Opstad, K., Guénette, C., 2000. Fire on the Sea Surface , Ignitability and Sustainability under Various Environmental Conditions, in: Fire Safety Science - Proceeding of the Sixth International Symposium. pp. 741-752.

Potter, S., Buist, I., 2008. In-Situ Burning for Oil Spills in Arctic Waters : State-of-the-Art and Future Research Needs, in: Davison, W.F., Lee, K., Cogswell, A. (Eds.), Oil Spill Response: A Global Perspective. Springer Dordrecht, pp. 23-39. https://doi.org/10.1007/978-1-4020-8565-9_5

Potter, S., Buist, I., Cooper, D., Schnabel, W., Garron, J., Perkins, R., Aggarwal, S., Bullock, R., Lane, P., 2016. Field Research on Helicopter Application of Chemical Herders to Advance InSitu Burning.

Rojas-Alva, U., Fritt-Rasmussen, J., Jomaas, G., 2019a. Experimental study of thickening effectiveness of two herders for in-situ burning of crude oils on water (Under review). Cold Reg. Sci. Technol.

Rojas-Alva, U., Fritt-Rasmussen, J., Jomaas, G., 2019b. Small-scale in-situ burning (ISB) experiments with chemically confined crude oils on water (Submitted). Combust. Sci. Technol.

Rojas Alva, U., Skjønning Andersen, B., Jomaas, G., 2018. Pumice stones as potential in-situ burning enhancer. Cold Reg. Sci. Technol. 146, 167-174. https://doi.org/10.1016/j.coldregions.2017.12.004

S.L. Ross Environmental Research Ltd., 2012. Research on Using Oil Herding Agents for Rapid Response In Situ Burning of Oil Slicks on Open Water - Final Report, S.L. Ross Environmental Research Ltd. Ottawa.

S.L. Ross Environmental Research Ltd., 2007. Mid-scale test tank research on using oil herding surfactants to thicken oil slicks in broken ice. Ottawa, Ontario.

Scholz, D., Warren, J., Walker, A.H., Micehl, J., 2004. In-Situ Burning: The fate of burned oil. API Publishing Services, Washington, D.C.

Shi, X., Bellino, P.W., Simeoni, A., Rangwala, A.S., 2016. Experimental study of burning behavior of large-scale crude oil fires in ice cavities. Fire Saf. J. 79, 91-99. https://doi.org/10.1016/j.firesaf.2015.11.007

Shigenaka, G., Overton, E., Meyer, B., Gao, H., Miles, S., 2015. Physical and chemical characteristics of In-situ burn residue and other environmental oil samples collected during the Deepwater Horizon spill response, in: Interspil Conference.

Singsaas, I., Cooper, D., Buist, I., Potter, S., Lewis, A., Daling, P.S., Bråtveit, M., 2017. Field experiment to validate herder and in-situ burning in open water, International Association of Oil \& Gas Producers.

Stout, S.A., Payne, J.R., 2016. Chemical composition of floating and sunken in-situ burn residues 
from the Deepwater Horizon oil spill. Mar. Pollut. Bull. 108, 186-202.

https://doi.org/10.1016/j.marpolbul.2016.04.031

The Federal Interagency Solutions Group, O.B.C.S. and E.T., 2010. Oil Budget Calculator:

Deepwater Horizon, Technical Documentation: A Report to the National Incident Command.

National Incident Command, Washington, D.C.

Van Gelderen, L., Brogaard, N.L., Sørensen, M.X., Fritt-Rasmussen, J., Rangwala, A.S., Jomaas, G., 2015. Importance of the slick thickness for effective in-situ burning of crude oil. Fire Saf. J. 78, 1-9. https://doi.org/10.1016/j.firesaf.2015.07.005

van Gelderen, L., Fritt-Rasmussen, J., Jomaas, G., 2016. Effectiveness of a chemical herder in association with in-situ burning of oil spills in ice-infested water. Mar. Pollut. Bull. https://doi.org/10.1016/j.marpolbul.2016.12.036

van Gelderen, L., Malmquist, L.M.V., Jomaas, G., 2017. Vaporization order and burning efficiency of crude oils during in-situ burning on water. Fuel 191, 528-537. https://doi.org/10.1016/j.fuel.2016.11.109

Walavalkar, A.Y., Kulkarni, A.K., 2001. Combustion of water-in-oil emulsion layers supported on water. Combust. Flame 125, 1001-1011. https://doi.org/10.1016/S0010-2180(01)00220-6 